\title{
Growth, leaf gas exchange and mycorrhizal colonization of three medicinal species submitted to different irradiance levels
}

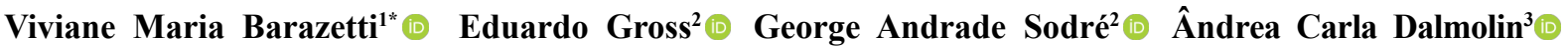 Larissa Corrêa do Bomfim Costa $^{4} \odot$ Miguel Antônio Quinteiro Ribeiro ${ }^{1} \odot$}

${ }^{1}$ Universidade Estadual de Santa Cruz (UESC), 45662-900, Ilhéus, BA, Brasil. E-mail barazetti.barazetti@gmail.com. "Corresponding author. ${ }^{2}$ Departamento de Ciências Agrárias e Ambientais, Universidade Estadual de Santa Cruz (UESC), Ilhéus, BA, Brasil. ${ }^{3}$ Centro de Formação em Ciências Agroflorestais, Universidade Federal do Sul da Bahia (UFSB), Itabuna, BA, Brasil. ${ }^{4}$ Departamento de Ciências Biológicas, Universidade Estadual de Santa Cruz, Ilhéus, BA, Brasil.

ABSTRACT: This study o evaluated growth, leaf gas exchange and arbuscular mycorrhizal fungi root colonization in three medicinal plant species under different irradiance intensities. Fridericia chica (Bonpl.) L.G.Lohmann, Mikania laevigata Sch.Bip. ex Baker and Varronia curassavica Jacq. were propagated by cutting and cultivated for 120 days in artificially shaded environments using black shade-type screens, obtaining four irradiance levels: $100 \%, 70 \%, 50 \%$ and 30\%. The experimental design was completely randomized in a $3 x 4$ factorial scheme (three plant species and four irradiation levels) with seven replicates. The three medicinal species showed higher liquid assimilation, mass growth and arbuscular mycorrhizal fungi root colonization rates when exposed to environments with $70 \%$ light availability. In relation to physiological responses, $V$. curassavica presented higher photosynthetic rate, stomatal conductance and transpiration when submitted to $70 \%$ irradiance, being able to be cultivated in more open environments with higher irradiation levels. Conversely F. chica and M. laevigata presented shade tolerance characteristics. At the initial growth phase, the results obtained can be used as indicators to recommend the ideal cultivation environment for these species in agroforestry systems.

Key words: light availability, biomass allocation, gas exchange, arbuscular mycorrhizal fungi.

Crescimento, trocas gasosas foliares e colonização micorrizica de três espécies de plantas medicinais submetidas a diferentes níveis de irradiância

RESUMO: O objetivo deste trabalho foi avaliar o crescimento, as trocas gasosas foliares e a colonização por fungos micorrizicos arbusculares em três espécies de plantas medicinais, sob diferentes intensidades de irradiância. Fridericia chica (Bonpl.) L.G. Ohmmann, Mikania laevigata Sch.Bip. ex Baker e Varronia curassavica Jacq. foram propagadas por estaquia e cultivadas por 120 dias em ambientes artificialmente sombreados, utilizando telas do tipo sombrite, em quatro níveis de irradiancia, 100\%, 70\%, 50\% e 30\%. O delineamento experimental foi inteiramente casualizado, em esquema fatorial $3 \times 4$ (três espécies de plantas e quatro níveis de irradiação) com sete repetições. As três espécies medicinais avaliadas apresentaram maiores taxas de assimilação líquida, crescimento em massa e colonização radicular por fungos micorrízicos arbusculares quando expostas a ambientes com $70 \%$ de disponibilidade de luz. Em relação às respostas fisiológicas, $V$. curassavica apresentou maior taxa fotossintética, condutância estomática e transpiração quando submetidas a 70\% de irradiância, podendo ser cultivada em ambientes mais abertos e com maiores niveis de radiação. Por outro lado, F. chica e M. laevigata apresentaram características de plantas tolerantes à sombra. Os resultados obtidos na fase inicial de crescimento podem ser utilizados como um indicador para recomendar o ambiente de plantio dessas três espécies medicinais em sistemas agroflorestais.

Palavras-chave: disponibilidade de luz, alocação de biomassa, trocas gasosas, fungos micorrízicos arbusculares.

\section{INTRODUCTION}

Fridericia chica (Bignoniaceae), Mikania laevigata (Asteraceae) and Varronia curassavica (Boraginaceae) are medicinal plants native to Brazil, with economic importance due to their active ingredients (LIMA et al. 2020). F. chica, popularly known as 'pariri', is used as anti-inflammatory (LIMA et al. 2020), healing and anti-anemic agent, and is also used to treat intestinal colic, hemorrhage, diarrhea and leukemia (BEHRENS et al., 2012). $M$. laevigata, commonly known as 'guaco', has leaves rich in coumarin and are used in the treatment of respiratory disorders, having anti-inflammatory action (DELLA PASQUA et al. 2019). V. curassavica, known as 'erva-baleeira', has anti-inflammatory activity (OLIVEIRA et al., 2020a) and is used as raw material for the first herbal medicine fully developed in Brazil, Acheflan ${ }^{\circ}$, which is based on the essential oil from this species (LIMA et al. 2020). 
In addition to medicinal properties, some studies have demonstrated various biological activities for the species, such as repellent for the control of urban ant Dorymyrmex thoracicus (OLIVEIRA et al. 2019), as well as antibacterial (RODRIGUES et al. 2012), anti-allergic (PASSOS et al., 2007), antifungal, and antiprotozoal action (NIZIO et al. 2018).

The quality of the raw material of medicinal plants is determined by the content of bioactive compounds, mainly resulting from the influence of the environment in which plants are grown. Biotic, abiotic and genetic factors influence the chemical composition of medicinal oils (BOARO et al, 2019). For example, for $V$. curassavica, changes in the content of bioactive compounds were observed due to changes in the light availability (SILVA et al. 2017), also depending on the time of year (MARQUES, et al. (2019) and the access used for collection (OLIVEIRA et al. (2020b). Studies carried out with the species have shown that in protected environments with $50 \%$ solar radiation incidence, it is possible to obtain higher levels of bioactive compounds such as transcaryophyllene, $\alpha$-humulene, germacrene D and $\alpha$-zingiberene (SILVA, 2017).

Similarly to what is observed for species of the genus Varronia, for species of the genus Mikania, TORMES (2019) demonstrated that plants grown in $50 \%$ full sun condition have higher coumarin levels, one of the main active principles of this genus. Therefore, understanding the ability of medicinal species to adapt to different light availability conditions allows determining the ideal cultivation conditions to achieve higher levels of biomass and active principles of economic and pharmacological interest.

Plants exposed to changes in irradiance levels have the ability to acclimate to a greater or lesser degree to the new condition. Acclimatization maximizes total carbon gain, which can occur through changes in leaf assimilation properties, physiological adjustments and changes in leaf characteristics related to photosynthesis or changes in the biomass allocation pattern in favor of the vegetative part more affected by light changes. The nature of the morphogenic response can vary considerably among $F$. chica, $M$. laevigata and $V$. Curassavica species according to the acclimatization capacity and dependence on the quantity or light quality (LIMA et al., 2008).

The ability of species to morphologically and physiologically acclimatize to variations in nutrient availability and to associate with arbuscular mycorrhizal fungi (AMF) favors the establishment of plants in environments with limited water and light availability. By establishing a symbiotic mutual association with the roots of most plant species, AMF promote an increase in the absorption of nutrients such as N, P, Zn, Mg and Ca (MATSUBARA et al. 2009, ZUBECK et al. 2015), increase in the levels of photosynthetic pigments in leaves (PEDONEBONFIM, et al. 2015) and higher production of primary metabolites, which are precursors of secondary metabolism pathways (MANOHARAN et al. 2010 and PEDONE-BONFIM, et al. 2015). Zengh et al. (2013) conducted a survey of studies with 49 different medicinal plants species and reported values from $6.42 \%$ to $765.56 \%$ higher of secondary compounds in plants that have associations with MFA, when compared to control plants.

This research evaluated the behavior of three medicinal species regarding growth, leaf gas exchange and arbuscular mycorrhizal fungi colonization submitted to different irradiance levels.

\section{MATERIALS AND METHODS}

The experiment was carried out at the State University of Santa Cruz (UESC), Ilhéus, BA from September 2017 to January 2018. F. chica, $M$. laevigata and $V$. curassavica plants obtained by cutting were transplanted into plastic pots with capacity of $10 \mathrm{~L}$ containing a mixture of soil and sand at proportion of $2: 1(\mathrm{v} / \mathrm{v})$. Initially, seedlings were rustified (submitted to rustication) in natural shade for a period of 30 days, and then submitted to treatments corresponding to four irradiance levels obtained by coverage with black screens corresponding to $100 \%$, $70 \%, 50 \%$ and $30 \%$ in relation to full sun. Within shade treatments, distance of $30 \mathrm{~cm}$ between plants was maintained, and plants were daily irrigated. No supplementary fertilization was carried out in the experimental period. Seedlings remained in treatments for a period of 120 days.

Leaf gas exchange, growth, chlorophyll index, and mycorrhizal colonization evaluations were carried out (described below). All material collection was carried out in a single day between 08:00 am and noon. Mycorrhizal colonization evaluation was carried out at laboratory as described below.

\section{Light availability assessment}

Photosynthetic active radiation (PAR) values were measured at the top of plants using BQM quantum sensor (Apogee Instruments USA). Evaluations were performed on 18 consecutive days from 07:00 am to 06:00 pm. The average PAR value observed at $100 \%$ irradiance was $34.2 \mu \mathrm{mol}$ photons $\mathrm{m}^{-2} \mathrm{~s}^{-1}$, followed by treatments of 26.0, 22.0 and 12.0 
$\mu \mathrm{mol}$ photons $\mathrm{m}^{-2} \mathrm{~s}^{-1}$, corresponding to $70 \%, 50 \%$ and $30 \%$ irradiance, respectively.

\section{Gas exchange evaluation}

Leaf gas exchange measurements were performed at the end of the experiment in two completely expanded and mature leaves of each individual per replicate. Net photosynthesis rates (Pn), stomatal conductance to water vapor (gs), and transpiration (E) were measured using portable photosynthesis system (LI-6400, LI-COR Bioscience, Lincoln, NE, USA), equipped with 6400-02B RedBlue artificial light source. Measurements were performed with equipment providing $1,000 \mu \mathrm{mol}$ photons $\mathrm{m}^{2} \mathrm{~s}^{-1}$, and chamber adjusted at $26{ }^{\circ} \mathrm{C}$, and ambient $\mathrm{CO}_{2}$ concentration $( \pm 380 \mu \mathrm{mol})$.

\section{Growth assessment}

At the beginning and end of the experiment, height and diameter of eight plants were measured using millimeter ruler and digital caliper, respectively, being collected from roots, stem and leaves. After measuring the total leaf area per plant, plants were stored and arranged to dry in forced air circulation oven at $75^{\circ} \mathrm{C}$ until reaching constant mass. Root dry mass (RDM), stem dry mass (SDM) leaf dry mass (LDM) and total dry mass (TDM) were determined. Leaf area (LA) was determined using LI-3100 leaf area meter (Li-Cor, Nebraska, USA).

From dry mass and leaf area data, specific leaf area (SLA), mean relative growth rate in mass (RGRm), diameter (RGRd) and height (RGRh), net assimilation (TAL), stem (SMF), leaf (LMR), and root (RMF) mass rates were calculated according to HUNT (1990).

\section{Chlorophyll Index}

At 120 days SPAD, chlorophyll index (ISPAD) was determined using portable SPAD chlorophyll meter (Minolta model SPAD-502). Two readings were made in fully expanded and mature leaves in four plants per treatment.

\section{Mycorrhizal colonization}

At the end of the experiment, the mycorrhizal colonization percentage in roots of three plants of each treatment was evaluated. Roots were cut and packed in plastic vials containing $100 \mathrm{~mL}$ of $70 \%$ ethanol, clarified and stained according to PHILLIPS \& HAYMAN (1970) method. Mycorrhizal colonization rate (COL), internal hyphal (HI), external hyphal (HE), vesicles (VES) and spores (ES) were evaluated by the intersection method of MCGONIGLE et al. (1990).
Data analysis

The experimental design was completely randomized (DIC) in a $3 \times 4$ factorial scheme (three species and four irradiance levels) with eight replicates. Results were submitted to analysis of variance (ANOVA), and when significant differences were observed, they were submitted to the Tukey test at 5\% probability using the Sisvar ${ }^{\circledR}$ software (FERREIRA, 2011).

\section{RESULTS AND DISCUSSION}

Variables RGRd, Pn, gs, E and spore percentage (ES) were influenced by one of the factors: species (Sp) or light (L). RGRh, RGRd, as well NAR, LMR, RMR, SLA, ISPAD, and variables related to mycorrhizal colonization (COL, HI, HE, and VES) were influenced by the species $\mathrm{x}$ light interaction (Table 1). The growth variables of species under study were influenced in different ways by light availability. The high RGRh, LMR and SLA values were observed with decreased radiation, while RGRm, NAR, SMR (except for F. chica) and RMR showed higher values with increased light availability (Table 2).

Higher RGRh value presented by plants under shade occurs in response to faster growth promoted by greater investment in cell stretching (MOTA et al., 2012), consisting of an important adaptation mechanism and an escape strategy at low luminosity conditions (YANG et al.2013; AMISSAH et al. 2015). Associated with this fact, the increase in SLA and ISPAD in environments with low light availability indicates greater carbon investment to capture light (TANG et al. 2015, COSTA et al. 2019), as an acclimatization strategy to this condition. The increase in chlorophyll content (ISPAD) under low light conditions has already been reported by other authors (FAVARETTO et al. 2011, CERQUEIRA et al. 2017) and aims to increase the light radiation assimilation efficiency (GONÇALVES et al. 2001). Conversely, the increase in RMR (root mass ratio) under conditions of greater light availability increases the water absorption by roots (POORTER, 2012). Under conditions of high irradiance, the demand for water increases and the greater carbon allocation to roots (higher RMR) ensures a balance between absorption and transpiration rates (COSTA et al. 2019).

Gas exchange variables (net photosynthesis $(\mathrm{Pn})$, stomatal conductance to water vapor (gs), and transpiration (E)) showed isolated effects of species and light regimes (Table 1). $V$. curassavicas presented higher $\mathrm{Pn}$, gs and $\mathrm{E}$ values when compared to the other species (Table 1), and 
Table 1 - Summary of the analysis of variance (ANOVA) for: RGRh - Relative growth rate in height (mg g $\left.\mathrm{g}^{-1} \mathrm{day}^{-1}\right)$; RGR - Relative growth rate in mass $\left(\mathrm{mg} \mathrm{g}^{-1} \mathrm{day}^{-1}\right)$; NAR- Net assimilation rate $\left(\mathrm{g} \mathrm{cm}^{2} \mathrm{day}^{-1}\right)$; LMR - leaf mass ratio; SMR - stem mass ratio; RMR - root mass ratio; SLA - specific leaf area $\left(\mathrm{cm} \mathrm{g}^{-1}\right)$; $\mathrm{Pn}$ - net photosynthetic rate $\left(\mu \mathrm{mol} \mathrm{m}^{-2} \mathrm{~s}^{-1}\right)$; gs - stomatal conductance to water vapor $\left(\mu \mathrm{mol} \mathrm{m} \mathrm{s}^{-2}\right)$; E - transpiration ratio $\left(\mathrm{mol} \mathrm{m}^{-2} \mathrm{~s}^{-1}\right)$; ISPAD - SPAD Index; COL - Mycorrhizal colonization rate; HI - internal hypha; HE - external hyphal; VES - vesicles e ES - spores for Fridericia chica (FC), Mikania laevigata (ML), Varronia curassavica (VC) growth at four levels of irradiance. (Sp: Species; L: Light; Sp x L: Species x Light).

\begin{tabular}{|c|c|c|c|c|c|c|c|c|c|c|}
\hline & \multicolumn{3}{|c|}{---------------------Species------------------- } & \multicolumn{4}{|c|}{------------Levels of Irradiance (\%)-------- } & \multicolumn{3}{|c|}{-----------ANOVA------- } \\
\hline & $\mathrm{FC}$ & ML & $\mathrm{VC}$ & 30 & 50 & 70 & 100 & $\mathrm{Sp}$ & $\mathrm{L}$ & SpxL \\
\hline RGRh & 5.70 & 7.13 & 4.83 & 7.18 & 5.54 & 5.60 & 5.23 & ** & $* *$ & *** \\
\hline RGRm & 25.24 & 22.38 & 24.27 & 22.14 & 22.70 & 26.68 & 24.27 & * & $* *$ & * \\
\hline NAR & 2.21 & 1.32 & 2.58 & 1.68 & 1.68 & 2.78 & 2.01 & ** & $* *$ & * \\
\hline LMR & 0.19 & 0.52 & 0.16 & 0.32 & 0.31 & 0.26 & 0.27 & ** & $* *$ & ** \\
\hline SMR & 0.32 & 0.34 & 0.62 & 0.44 & 0.40 & 0.45 & 0.42 & ** & * & * \\
\hline RMR & 0.48 & 0.22 & 0.21 & 0.23 & 0.29 & 0.27 & 0.31 & ** & ** & * \\
\hline SLA & 130.40 & 109.90 & 150.10 & 195.40 & 128.90 & 102.30 & 94.00 & ** & ** & * \\
\hline Pn & 9.45 & 8.06 & 12.68 & 9.29 & 9.19 & 11.05 & 10.74 & $* *$ & $* *$ & ns \\
\hline gs & 0.18 & 0.12 & 0.33 & 0.18 & 0.20 & 0.23 & 0.22 & ** & * & ns \\
\hline $\mathrm{E}$ & $3.45 \mathrm{~b}$ & $2.66 \mathrm{c}$ & $5.73 \mathrm{a}$ & 3.94 & 3.90 & 4.28 & 3.66 & ** & * & ns \\
\hline$I S P A D$ & 37.90 & 37.60 & 22.20 & 37.30 & 30.10 & 30.8 & 32.10 & $* *$ & $* *$ & $* *$ \\
\hline $\mathrm{COL}$ & 56.30 & 66.30 & 72.90 & 57.30 & 59.50 & 75.00 & 68.50 & ** & $* *$ & $* *$ \\
\hline $\mathrm{HI}$ & 34.70 & 36.60 & 46.10 & 28.90 & 38.60 & 46.90 & 42.00 & ** & $* *$ & $* *$ \\
\hline $\mathrm{HE}$ & 22.40 & 23.90 & 23.40 & 21.00 & 21.10 & 25.50 & 25.50 & ns & $* *$ & $* *$ \\
\hline VES & 32.30 & 23.50 & 33.00 & 25.00 & 23.40 & 34.80 & 35.40 & $* *$ & $* *$ & $* *$ \\
\hline ES & $2.40 \mathrm{~b}$ & $0.60 \mathrm{~b}$ & $9.70 \mathrm{a}$ & 2.60 & 4.30 & 3.80 & 6.70 & ** & ns & ns \\
\hline
\end{tabular}

$\left(^{*}\right) \mathrm{P}>0.05$ e $\left(^{* *}\right) \mathrm{P}>0.01$ e (ns) not significant.

Lowercase letters indicate values that differ only between species.

higher values were observed in treatments of $70 \%$ and $100 \%$ irradiance. These high $\mathrm{Pn}$, gs and E values demonstrated the ability of plants to physiologically acclimate to high irradiance conditions, corroborating its classification as heliophilous (SMITH, 1970). The increase in Pn values occurs at the expense of higher gas exchange and $\mathrm{E}$ values when greater light availability (DALMOLIN et al. 2015) and low irradiance environments have greater stomatal control and; consequently, higher water use efficiency (KARATASSIOU \& NOITSAKIS 2010).

In relation to mycorrhizal colonization, the highest radiation levels promote greater mycorrhizal colonization rate (COL), internal hyphal (HI), external hyphal (HE) (except for M. laevigata) and vesicles (VES) values (except for F. chica) (Table 3). Among these three species, $V$. curassavica presented the highest COL, HI and VES values. Arbuscular mycorrhizal fungi (AMF) have symbiotic relationships with plants, constituting a specific type of ecological relation, mutualism, in which both components benefit from the interaction (SMITH \& SMITH 2011). The irradiance levels significantly influence AMF colonization, presenting better results in environments with higher irradiance levels. In environments with low irradiance levels, $F$. chica, M. laevigata and $V$. curassavica species presented low colonization and low RMR, and the lower the proportion of roots, the lower the AMF colonization. This is probably due to lower carbon translocation to roots, which implies lower amount of exudate for AMF maintenance, requiring photosynthesis products from the host plant (GEHRING, 2013).

Mycorrhiza increase the uptake of water and nutrients from soil to plants by means of two absorption paths. One by root epidermis and root trichomes, the other by AMF extraradicular hypha and symbiotic cortical arbuscule cell interface (SMITH \& SMITH 2011). In fact, for $F$. chica and $V$. curassavica species, higher EH percentage (extraradicular hyphae) was observed for higher irradiance environment, where biomass partition for roots was higher.

\section{CONCLUSION}

Young $F$. chica, M. laevigata and $V$. curassavica plants showed morpho-physiological 
Table 2 - Mean values ( $\pm \mathrm{se})$ for relative growth rate in height $(\mathrm{RGRh} \mathrm{cm} \mathrm{cm} 1$ day -1$)$, relative growth rate in mass $\left(\mathrm{RGRm}, \mathrm{mg} \mathrm{g}^{-1}\right.$ day $^{-1}$ ), net assimilation rate (NAR, $\mathrm{g} \mathrm{cm}^{2}$ day $^{-1}$ ) leaf mass ratio (LMR), stem mass ratio (SMR), root mass ratio (RMR), specific leaf area (SLA, $\mathrm{cm}^{2} \mathrm{gr}^{-1}$ ) and SPAD Index (SPAD) of Fridericia chica (FC), Mikania laevigata (ML), Varronia curassavica (VC) growth at four levels of irradiance.

\begin{tabular}{|c|c|c|c|c|c|}
\hline \multirow[t]{2}{*}{ Variables } & \multirow[t]{2}{*}{ Species } & \multicolumn{4}{|c|}{ - } \\
\hline & & 30 & 50 & 70 & 100 \\
\hline \multirow{3}{*}{ RGRh } & $\mathrm{FC}$ & $5.38 \pm 2.04 \mathrm{Ba}$ & $5.94 \pm 0.74 \mathrm{Aa}$ & $5.49 \pm 1.65 \mathrm{Aa}$ & $6.09 \pm 1.00 \mathrm{Aa}$ \\
\hline & ML & $8.67 \pm 0.99 \mathrm{Aa}$ & $7.48 \pm 0.74 \mathrm{Aab}$ & $6.45 \pm 0.98 \mathrm{Ab}$ & $5.92 \pm 0.75 \mathrm{Ab}$ \\
\hline & $\mathrm{VC}$ & $7.49 \pm 0.96 \mathrm{Aa}$ & $3.19 \pm 1.53 \mathrm{Bb}$ & $4.83 \pm 1.65 \mathrm{Ab}$ & $3.78 \pm 0.93 \mathrm{Bb}$ \\
\hline \multirow{3}{*}{ RGRm } & $\mathrm{FC}$ & $22.08 \pm 2.75 \mathrm{Ab}$ & $25.45 \pm 2.70 \mathrm{Aa}$ & $26.42 \pm 1.39 \mathrm{Aa}$ & $27.01 \pm 1.72 \mathrm{Aa}$ \\
\hline & ML & $21.30 \pm 1.75 \mathrm{Ab}$ & $20.89 \pm 2.91 \mathrm{Bb}$ & $26.27 \pm 2.40 \mathrm{Aa}$ & $21.03 \pm 2.88 \mathrm{Bb}$ \\
\hline & $\mathrm{VC}$ & $23.04 \pm 2.14 \mathrm{Ab}$ & $21.97 \pm 2.15 \mathrm{Bb}$ & $27.35 \pm 2.54 \mathrm{Aa}$ & $24.73 \pm 1.56 \mathrm{Aab}$ \\
\hline \multirow{3}{*}{ NAR } & $\mathrm{FC}$ & $1.56 \pm 0.54 \mathrm{Bb}$ & $2.21 \pm 0.54 \mathrm{Aab}$ & $2.50 \pm 0.63 \mathrm{Ba}$ & $2.58 \pm 0.70 \mathrm{Aa}$ \\
\hline & ML & $1.15 \pm 0.32 \mathrm{Bb}$ & $1.02 \pm 0.22 \mathrm{Bb}$ & $2.08 \pm 0.18 \mathrm{Ba}$ & $1.03 \pm 0.46 \mathrm{Bb}$ \\
\hline & $\mathrm{VC}$ & $2.33 \pm 0.52 \mathrm{Ab}$ & $1.82 \pm 0.59 \mathrm{Ab}$ & $3.76 \pm 0.48 \mathrm{Aa}$ & $2.42 \pm 0.55 \mathrm{Ab}$ \\
\hline \multirow{3}{*}{ SMR } & $\mathrm{FC}$ & $0.37 \pm 0.03 \mathrm{Ba}$ & $0.32 \pm 0.03 \mathrm{Bab}$ & $0.33 \pm 0.05 \mathrm{Bab}$ & $0.28 \pm 0.04 \mathrm{Cb}$ \\
\hline & ML & $0.32 \pm 0.02 \mathrm{Bb}$ & $0.32 \pm 0.04 \mathrm{Bab}$ & $0.37 \pm 0.02 \mathrm{Bab}$ & $0.38 \pm 0.03 \mathrm{Ba}$ \\
\hline & $\mathrm{VC}$ & $0.64 \pm 0.04 \mathrm{Aab}$ & $0.57 \pm 0.10 \mathrm{Ac}$ & $0.67 \pm 0.03 \mathrm{Aa}$ & $0.60 \pm 0.02 \mathrm{Abc}$ \\
\hline \multirow{3}{*}{ RMR } & $\mathrm{FC}$ & $0.42 \pm 0.03 \mathrm{Ac}$ & $0.49 \pm 0.05 \mathrm{Ab}$ & $0.45 \pm 0.07 \mathrm{Abc}$ & $0.57 \pm 0.05 \mathrm{Aa}$ \\
\hline & ML & $0.10 \pm 0.03 \mathrm{Cc}$ & $0.12 \pm 0.02 \mathrm{Cab}$ & $0.16 \pm 0.03 \mathrm{Ba}$ & $0.13 \pm 0.03 \mathrm{Cab}$ \\
\hline & $\mathrm{VC}$ & $0.17 \pm 0.04 \mathrm{Bc}$ & $0.25 \pm 0.08 \mathrm{Ba}$ & $0.21 \pm 0.02 \mathrm{Bab}$ & $0.22 \pm 0.02 \mathrm{Bab}$ \\
\hline \multirow{3}{*}{ SLA } & $\mathrm{FC}$ & $225.70 \pm 56.3 \mathrm{Aa}$ & $115.30 \pm 16.0 \mathrm{Bb}$ & $88.70 \pm 25.9 \mathrm{Bb}$ & $91.90 \pm 5.1 \mathrm{Ab}$ \\
\hline & ML & $161.20 \pm 19.5 \mathrm{Ba}$ & $109.30 \pm 6.4 \mathrm{Bb}$ & $84.60 \pm 39.1 \mathrm{Bb}$ & $84.60 \pm 6.6 \mathrm{Ab}$ \\
\hline & $\mathrm{VC}$ & $199.30 \pm 16.5 \mathrm{Aa}$ & $162.20 \pm 17.5 \mathrm{Ab}$ & $133.40 \pm 15.5 \mathrm{Abc}$ & $105.60 \pm 8.5 \mathrm{Ac}$ \\
\hline \multirow{3}{*}{ ISPAD } & $\mathrm{FC}$ & $47.40 \pm 0.7 \mathrm{Aa}$ & $32.00 \pm 2.5 \mathrm{Bc}$ & $36.30 \pm 4.5 \mathrm{Ab}$ & $36.30 \pm 1.8 \mathrm{Ab}$ \\
\hline & ML & $40.60 \pm 3.9 \mathrm{Ba}$ & $38.40 \pm 3.7 \mathrm{Aa}$ & $32.00 \pm 4.5 \mathrm{Bb}$ & $39.40 \pm 2.3 \mathrm{Aa}$ \\
\hline & $\mathrm{VC}$ & $24.00 \pm 3.1 \mathrm{Ca}$ & $20.10 \pm 1.1 \mathrm{Ca}$ & $24.00 \pm 3.8 \mathrm{Ca}$ & $20.70 \pm 2.2 \mathrm{Ba}$ \\
\hline
\end{tabular}

Means followed by the same capital letter do not differ between species, and means followed by the same lowercase letters do not differ between light environments. Tukey test $(\mathrm{P}>0.05)$. Mean values of five replicates $( \pm \mathrm{SD})$.

Table 3 - Mean values ( \pm se) for mycorrhizal colonization rate (COL), internal hypha (HI), external hyphal (HE) and vesicle (VES) of roots of Fridericia chica (FC), Mikania laevigata (ML), Varronia curassavica (VC) growth at four levels of irradiance.

\begin{tabular}{|c|c|c|c|c|c|}
\hline \multirow{2}{*}{$\begin{array}{l}\text { Variable } \\
(\%)\end{array}$} & \multirow[t]{2}{*}{ Species } & \multicolumn{4}{|c|}{ 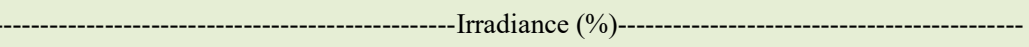 } \\
\hline & & 30 & 50 & 70 & 100 \\
\hline \multirow{3}{*}{$\mathrm{COL}$} & FC & $45.0 \pm 4.0 \mathrm{Cc}$ & $51.78 \pm 1.7 \mathrm{Bb}$ & $72.0 \pm 2.0 \mathrm{Ba}$ & $56.5 \pm 3.0 \mathrm{Cb}$ \\
\hline & ML & $57.6 \pm 0.9 \mathrm{Bb}$ & $55.1 \pm 3.2 \mathrm{Bb}$ & $73.9 \pm 2.5 \mathrm{Aba}$ & $78.8 \pm 3.8 \mathrm{Aa}$ \\
\hline & $\mathrm{VC}$ & $69.5 \pm 1.7 \mathrm{Ab}$ & $71.8 \pm 2.2 \mathrm{Ab}$ & $79.1 \pm 2.9 \mathrm{Aa}$ & $71.0 \pm 2.7 \mathrm{Bb}$ \\
\hline \multirow{3}{*}{ HI } & $\mathrm{FC}$ & $17.4 \pm 1.0 \mathrm{Cc}$ & $32.9 \pm 2.2 \mathrm{Bb}$ & $46.0 \pm 1.0 \mathrm{Ba}$ & $42.5 \pm 1.8 \mathrm{Aa}$ \\
\hline & ML & $29.9 \pm 3.3 \mathrm{Bc}$ & $34.8 \pm 1.5 \mathrm{Bbc}$ & $42.5 \pm 1.7 \mathrm{Ba}$ & $39.2 \pm 3.7 \mathrm{Aab}$ \\
\hline & $\mathrm{VC}$ & $39.5 \pm 2.3 \mathrm{Ac}$ & $48.3 \pm 2.9 \mathrm{Aab}$ & $52.1 \pm 1.8 \mathrm{Aa}$ & $44.5 \pm 2.0 \mathrm{Abc}$ \\
\hline \multirow{3}{*}{$\mathrm{HE}$} & $\mathrm{FC}$ & $15.1 \pm 3.3 \mathrm{Cc}$ & $19.0 \pm 0.6 \mathrm{Bb}$ & $29.3 \pm 1.8 \mathrm{Aa}$ & $26.4 \pm 1.2 \mathrm{Aa}$ \\
\hline & ML & $26.3 \pm 2.6 \mathrm{Aab}$ & $27.0 \pm 0.6 \mathrm{Aa}$ & $19.9 \pm 1.1 \mathrm{Bc}$ & $22.6 \pm 1.4 \mathrm{Bbc}$ \\
\hline & VC & $21.4 \pm 1.9 \mathrm{Bb}$ & $17.4 \pm 1.0 \mathrm{Bc}$ & $27.3 \pm 2.1 \mathrm{Aa}$ & $27.6 \pm 1.0 \mathrm{Aa}$ \\
\hline \multirow{3}{*}{ VES } & $\mathrm{FC}$ & $26.8 \pm 3.8 \mathrm{Ab}$ & $24.5 \pm 3.0 \mathrm{Ab}$ & $34.6 \pm 4.4 \mathrm{Bb}$ & $43.2 \pm 3.0 \mathrm{Aa}$ \\
\hline & ML & $17.0 \pm 1.2 \mathrm{Bb}$ & $24.1 \pm 3.3 \mathrm{Aa}$ & $28.7 \pm 1.4 \mathrm{Ca}$ & $24.2 \pm 4.7 \mathrm{Ba}$ \\
\hline & $\mathrm{VC}$ & $31.1 \pm 2.3 \mathrm{Ab}$ & $21.5 \pm 0.5 \mathrm{Ac}$ & $41.1 \pm 1.9 \mathrm{Aa}$ & $38.6 \pm 1.5 \mathrm{Aa}$ \\
\hline
\end{tabular}

Means followed by the same capital letter do not differ between species, and means followed by the same lowercase letters do not differ between light environments. Tukey test $(\mathrm{P}>0.05)$. Mean values of five replicates $( \pm \mathrm{SD})$. 
changes that enable them to survive under different irradiance levels. The three medicinal species evaluated showed higher liquid assimilation rate, higher mass growth rate and greater mycorrhizal fungi colonization when exposed to environments with $70 \%$ light availability. However, V. curassavicas seems to be more acclimatized in environments with greater light availability, while $F$. chica and $M$. laevigata can be grown in more shaded environments.

\section{ACKNOWLEDGMENTS}

The authors would like to thank the Coordenação de Aperfeiçoamento de Pessoal de Nível Superior (CAPES) Financing Code 001, for Viviane Maria Barazetti scholarship. Ândrea Dalmolin would like to thank Conselho Nacional de Desenvolvimento Científico e Tecnológico (CNPq) for the scientific productivity award (307604/2020-9). To the "Programa de Pós Graduação em Produção Vegetal UESC" and the "Comissão Executiva do Plano da Lavoura Cacaueira" (CEPLAC) for the institutional support and facilities for carrying out this work.

\section{DECLARATION OF CONFLICT OF INTEREST}

We have no conflict of interest to declare.

\section{AUTHORS' CONTRIBUTIONS}

All authors equally contributed to the design and writing of the manuscript. All authors critically reviewed the manuscript and approved the final version.

\section{REFERENCES}

AMISSAH, L. et al. The Effects of Drought and Shade on the Performance, Morphology and Physiology of Ghanaian Tree Species. PLOS ONE, v.10, n.4, 2015. Available from: $<$ https://doi. org/10.1371/journal.pone.0121004>. Accessed: Apr. 04, 2021. doi: 10.1371/journal.pone.0121004.

BOARO, C. S. F. et al. Factors influencing the production and chemical composition of essential oils in aromatic plants from Brazil. In: MALIK S. (eds) Essential Oil Research, Springer, Cham. p.19-47, 2019. Available from: <https://doi. org/10.1007/978-3-030-16546-8 2>. Accessed: Sep. 22, 2020.

BEHRENS, M. D. D. et al. Arrabidaea chica (Humb. \& Bonpl.) B. Verlot (Bignoniaceae). Revista Fitos Eletrônica, v.7, p.236244, 2012. Available from: <https://www.arca.fiocruz.br/handle/ icict/15126>. Accessed: Sep. 23, 2020.

CERQUEIRA, A. F. et al. Photosynthetic plasticity of young plants of Carpotroche brasiliensis (Raddi) A. Gray, Achariaceae. Trees, v.32, p.191-202, 2018. Available from: <https://link.springer.com/ article/10.1007/s00468-017-1623-6>. Accessed: Aug. 20, 2020.

COSTA, G. S. et al. Physiological and growth strategies of two Cariniana species in response to contrasting light availability. Flora, v.258, p.1-8, 2019. Available from: <https://www.sciencedirect.com/ science/article/pii/S0367253018306212>. Accessed: Sep. 25, 2020.
DALMOLIN, A. C. et al. Alterações morfofisiológicas de plantas jovens de Curatella americana L. submetidas ao sombreamento. Brazilian Journal of Biosciences, v.13, n.1, p.41-48, 2015. Available from: <http://www.ufrgs.br/seerbio/ojs/index.php/rbb/ article/view/3195>. Accessed: Sep. 22, 2020.

DELLA PASQUA, C. S. P. Pharmacological study of antiinflammatory activity of aqueous extracts of Mikania glomerata (Spreng.) and Mikania laevigata (Sch. Bip. ex Baker). Journal of Ethnopharmacology. v.231, p.50-56. 2019. Available from: <https://doi.org/10.1016/j.jep.2018.11.012>. Accessed: Sep. 22, 2020.

FAVARETTO, V. F. et al. Differential responses of antioxidant enzymes in pioneer and latesuccessionaltropical tree species grown under sun and shadeconditions. Environmental Experimental Botany, v.70: p.20-28. 2011. Available from: <https://www. sciencedirect.com/science/article/abs/pii/S0098847210001437>. Accessed: Sep. 22, 2020.

FERREIRA, D. F. Sisvar: a computer statistical analysis system. Ciência e Agrotecnologia, n.35, p.1039-1042. 2011. Available from: <https://www.scielo.br/j/cagro/a/yjKLJXN9KysfmX6rvL9 3TSh/?lang=en $>$. Accessed: Sep. 18, 2020. doi: 10.1590/S1413$70542011000600001>$.

GONÇALVES, J.F. D. C. Concentration of photosynthetic pigments and chlorophyll fluorescence of mahogany and tonka bean under two light environments. Revista Brasileira de Fisiologia Vegetal, v.13: p.149-157. 2001. Available from: <http://www.scielo.br/ scielo.php?script=sci_arttext\&pid=S0103-31312001000200004 $>$. Accessed: Sep. 07, 2020.

GEHRING, C. A. Growth responses to arbuscular mycorrhizae by rain forest seedlings vary with light intensity and tree species. Plant Ecology, v.167, p.127-139, 2013. Available from: <https:// doi.org/10.1023/A:1023989610773>. Accessed: Sep. 22, 2020. doi: 10.1023/A:1023989610773.

HUNT, R. Basic Growth Analysis. Springer Netherlands, Dordrecht. 1990.

KARATASSIOU, M.; NOITSAKIS, B. Changes of the photosynthetic behaviour in annual $\mathrm{C} 3$ species at late successional stage under environmental drought conditions. Photosynthetica, v.48, p.377-382, 2010. Available from: <https://www.researchgate. net/publication/251393889>. Accessed: Set. 22, 2020. doi: 10.1007/s11099-010-0049-9.

LIMA, J. C. S. et al. Anti-inflammatory activity of 4',6,7-trihydroxy-5-methoxyflavone from Fridericia chica (Bonpl.) L.G.Lohmann. Natural Product Research, v.34, n.5, p.726-730. 2020. Available from: <https://www. tandfonline.com/doi/full/10.1080/14786419.2018.1495636?s croll $=$ top \&needAccess $=$ true $>$. Accessed: Sep. 16, 2020. doi: 10.1080/14786419.2018.1495636.

LIMA, J.D. etal.Efeitos daluminosidade no crescimentodemudas de Caesalpinia ferrea Mart. ex Tul. (Leguminosae, Caesalpinoideae). Acta Amazonica, v.38, p.5-10. 2008. Available from: <http:// www.scielo.br/scielo.php? script $=$ sci arttext\&pid $=$ S004459672008000100002\&lng=pt\&tlng=pt $>$. Accessed: Aug. 16, 2020. doi: 10.1590/S0044-59672008000100002.

MARQUES, A. P. S. et al. Chemical composition of essential oil from Varronia curassavica Jacq. accessions in different seasons of 
the year. Industrial Crops and Products, v.140, p.111656. 2019. Available from: <https://doi.org/10.1016/j.indcrop.2019.111656>. Accessed: Aug. 19, 2020.

MANOHARAN, P. T. Influence of AM fungi on the growth and physiological status of Erythrina variegata Linn. grown under different water stress conditions. European Journal Soil Biology, v.46, p.151-156, 2010. Available from: <https://www.researchgate. net/signup.SignUp.html>. Accessed: Apr. 04, 2021.

MATSUBARA, A. D. G. et al. Sun-shade patterns of leaf carotenoid composition in 86 species of neotropical forest plants. Plant, Cell and Environment, v.31, p.548-561, 2008. Available from: <https://www.publish.csiro.au/FP/FP08214>. Accessed: Apr. 04, 2021. doi: 10.1111/j.1365-3040.2008.01788.x.

MOTA, L. H. D. E S. et al. Sombreamento na emergência de plântulas e no crescimento inicial de Dipteryx alata Vog. Ciência Florestal, v.22, n.3, p.423-431, 2012. Available from: <https:// periodicos.ufsm.br/cienciaflorestal/article/view/6611>. Accessed: Aug. 20, 2020

MCGONIGLE, T. P. et al. A new method which gives an objective measure of colonization of roots by vesicular - arbuscular mycorrhizal fungi. New Phytologist, 115:495-501. 1990. Available from: $\quad<$ https://www.scienceopen.com/document?vid=5bdc48dd9ae6-4cfe-8e85-653800529042>. Accessed: Apr. 04, 2021. doi: 10.1111/j.1469-8137.1990.tb00476.x.

NIZIO, D. A. C. et al. Essential oils of Varronia curassavica accessions have different activity against white spot disease in freshwater fish. Parasitology Research, v.117, p.97-105. 2018. Available from: <https://doi.org/10.1007/s00436-017-5673-x>. Accessed: Sep. 20, 2020.

OLIVEIRA, B. M. S. et al. Essential oils from Varronia curassavica (Cordiaceae) accessions and their compounds (E)-caryophyllene and $\alpha$-humulene as an alternative to control Dorymyrmex thoracius (Formicidae: Dolichoderinae). Environmental Science and Pollution Research, v.26, p.6602-6612, 2019. Available from: $<$ https://doi.org/10.1007/s11356-018-4044-1>. Accessed: Apr. 5, 2021.

OLIVEIRA, B. M. S. et al. Morpho-Agronomic Characterization Of Varronia curassavica Germplasm Conservated "Ex Situ". Bioscience Journal, Uberlândia, v.36, n.2, p.353363, 2020a. Available from: <http://dx.doi.org/10.14393/BJv36n2a2020-42275>. Accessed: Apr. 5, 2021.

OLIVEIRA, B. M. S. et al. Chemical analyses of the essential oils from Varronia curassavica accessions in two seasons. Journal of Essential Oil Research, v32, n.6, p.494-511. 2020b. Available from: $\quad<$ https://doi.org/10.1080/10412905.2020.1789001>. Accessed: Aug. 20, 2020

PASSOS, G. F. et al. Anti-inflammatory and anti-allergic properties of the essential oil and active compounds from Cordia verbenacea. Journal of Ethnopharmacology, v.110, p.323-333, 2007. Available from: <https://doi.org/10.1016/j.jep.2006.09.032>. Accessed: Set.18, 2020.

PEDONE-BONFIM et al. Production of secondary metabolites by mycorrhizal plants with medicinal or nutritional potential. Acta Physiologia Plantarum, v.37, p.27, 2015 Available from:
$<$ https://link.springer.com/article/10.1007/s11738-015-1781-3>. Accessed: Apr. 04, 2021.

PHILLIPS, J. M.; HAYMAN, D. S. Improved procedures for clearing roots and staining parasitic and vesicular-arbuscular mycorrhizal fungi for rapid assessment of infection. Transactions of the British Mycological Society, v.55, p.158-IN18, 1970. Available from: $<$ http://linkinghub.elsevier.com/retrieve/pii/S0007153670801103>. Accessed: Sep. 18, 2020. doi: 10.1016/S0007-1536(70)80110-3.

POORTER H. et al. Mommer L. Biomass allocation to leaves, stems and roots: meta-analyses of interspecific variation and environmental control: Tansley review. New Phytologist, v.193, p.30-50, 2012. Available from: <https://nph.onlinelibrary.wiley. com/doi/full/10.1111/j.1469-8137.2011.03952.x>. Accessed: Sep. 18, 2020. doi: 10.1111/j.1469-8137.2011.03952.x.

RODRIGUES, F. F. G. et al. Chemical composition, antibacterial and antifungal activities of essential oil from Cordia verbenacea DC leaves. Pharmacognosy Research, v.4, p.161-165, 2012. Available from: <https://doi.org/10.4103/0974-8490.99080>. Accessed: Aug. 18, 2020.

SILVA, J. H. S. Influência do ambiente de cultivo em acessos de erva-baleeira (Varronia curassavica Jacq.). 2017. 40 f. Dissertação (Mestrado em Agricultura e Biodiversidade) Universidade Federal de Sergipe, São Cristóvão, SE, 2017. Available from: $\quad<$ https://ri.ufs.br/jspui/handle/riufs/6780>. Accessed: Sep. 18, 2020.

SMITH, L. B. Boragináceas. In: REITZ, R. editor. Flora Ilustrada Catarinense. Itajaí: Herbário Barbosa Rodrigues, 1970.

SMITH, S. E.; SMITH, F. A. Roles of arbuscular mycorrhizas in plant nutrition and growth: New paradigms from cellular to ecosystem scales. Annual Review of Plant Biology, v.62, p.227250. 2011. Available from: <https://www.annualreviews.org/ doi/10.1146/annurev-arplant-042110-103846>. Accessed: Sep. 18, 2020. doi: 10.1146/annurev-arplant-042110-103846.

TANG, H. et al. Growth, photosynthetic and physiological responses of Torreya grandis seedlings to varied light environments. Trees, v.29, p.1011-1022, 2015. Available from: <https://link.springer. com/article/10.1007/s00468-015-1180-9>. Accessed: Apr. 04, 2021. doi 10.1007/s00468-015-1180-9.

TORMES, F. Produção de biomassa, teor de cumarina e análise foliar de plantas de guaco (MikaniaglomerataSprengel) cultivadas sob diferentes fontes de adubação e luminosidade. Trabalho de Conclusão de Curso (Licenciatura em Ciências Biológicas) - Universidade Tecnológica Federal do Paraná, Santa Helena, 2019. Available from: $<$ http://repositorio.roca.utfpr.edu.br/ jspui/handle/1/16642>. Accessed: Sep. 18, 2020.

YANG, W. et al. Growth and photosynthetic responses of Canarium pimela and Nephelium topengii seedlings to a light gradient. Agroforest Syst, v.87, p.507-516, 2013. Available from: <https:// link.springer.com/article/10.1007/s10457-012-9570-0>. Accessed: Apr. 4, 2021. doi: 10.1007/s10457-012-9570-0.

ZUBECK, et al. Enhanced concentrations of elements and secondary metabolites in Viola tricolor L. induced by arbuscular mycorrhizal fungi. Plant Soil, v.390, p.129-142. 2015 Available from: $<$ https://doi. org/10.1007/s11104-015-2388-6>. Accessed: Sep. 18, 2020. 